\title{
Determinants Of Economic Growth: Evidence From American Countries
}

Hong Zhuang, Indiana University South Bend, USA

Robert St. Juliana, Indiana University South Bend, USA

\begin{abstract}
This paper explores determinants of economic growth using variables from traditional Solow model and recent empirical studies. The study covers data on American countries during the period 1995-2006. The estimates show that per capita, GDP growth is positively related to capital expenditure, primary completion rate and trade openness and the relationship is statistically significant. Furthermore, population growth rate and investment in research and development have positive impacts on economic growth, yet the effects are not significant.
\end{abstract}

Keywords: economic growth, capital accumulation rate, education, trade

\section{INTRODUCTION}

conomic growth, which is often measured as per capita GDP growth, not only indicates a country's economic performance in a year, but also reflects its residents' welfare, to certain extent. A sustainable economic growth is essential for a country's long-term development and stability. Hence, it is of interests for policy makers and economists to explore variables affecting economic growth. The answer to this question can help the government to evaluate its development policy, allocate country resources more efficiently, or improve domestic welfare.

Theories study and empirical practice complement each other to amplify the growth literature. Hence, it's the aim of this paper to conduct an empirical study on economic growth using variables suggested by economic theories and empirical findings. We include traditional variables in the Solow model and variables reflecting the quality of labor force, technological progress and country openness in the estimation and use of data from American countries covering the period 1996-2005. Major findings are that the Solow model variables - capital accumulation rate and population growth rate - are positively related to economic growth. Meanwhile, primary completion rate, the share of research and development expenditure in GDP, and the share of exports and imports in GDP have a positive impact on economic growth as well. Among the variables, the coefficients of capital accumulation rate, primary completion rate, and the share of exports and imports in GDP are statistically significant. The findings of this paper are consistent with the Solow model prediction and other empirical findings on determinants of economic growth.

Section 2 provides a brief survey on the growth literature; Section 3 presents the econometric model to investigate the variables affecting economic growth; Section 4 describes the data used in this paper; Section 5 presents the analysis of the empirical results; and Section 6 concludes the paper.

\section{LITERARY REVIEW}

The Solow growth model postulates that economic performance is attributed capital accumulation and population growth rate. As growth theory advances, other growth theorists including Paul Romer, Robert E. Lucas and Robert J. Barro postulate that technological progress and human capital related to labor effectiveness affect economic growth as well. Thereafter, a number of studies examine the impact of education and research and development $(\mathrm{R} \& \mathrm{D})$ on economic growth through the channel of improving the labor effectiveness. Davidson and Segerstrom (1998) develop an endogenous growth model to investigate the effect of innovative R\&D and imitative 
R\&D on economics growth. ${ }^{1}$ They find that although both types of $R \& D$ create new knowledge which benefits consumers, only innovative R\&D subsidies lead to faster economic growth; imitative R\&D subsidies lead to slower economic growth (Davidson and Segerstrom, 1998). Jones (2002) conducts an empirical study using the U.S. data from 1950 to 1993 and finds that post-secondary education and R\&D can account for up to $80 \%$ of economic growth in a country in the short run.

With the growing importance of stock markets around the world, a new avenue of research looks into the impact of stock markets on economic growth. Yet the studies are inconclusive (Levine and Zervos, 1998; Atje and Jovanovic, 1993) though the theory may suggest that well developed stock markets indicate high degree of financial development, which facilitates channels between capital accumulation and economic growth. The research attention is then turned to stock market volatility. Arestis et al (2001) uses times series data on Germany, France, Japan, the United Kingdom, and the United States and find that stock market volatility has negative effect on output growth in Japan, France and the United Kingdom; yet the effect in the Germany and the United States is insignificant. Furthermore, Arestis et al (2001) find that the contribution of stock market to economic growth is a small fraction of that of the banking system.

A large strand of economic literature is on the relationship between trade and economic growth. As theory suggested, trade is related to economic growth through different channels. Trade serves a transmission channel of capital, non-capital goods or knowledge between domestic countries and the rest of the world which stimulates productivity and thus economic growth (Romer, 1990). Trade may promote economic growth through introducing the economies of scale and improving the optimal allocation of resources between commodity production sector and knowledge production sector (Helpman, 1981; Krugman, 1979). A number of empirical studies provide supporting evidence on the connection between trade and economic growth (Coe and Helpman, 1995; Xu and Wang, 1999).

\section{ECONOMETRIC MODEL}

Based on the Solow model and the previous studies on growth, the following econometric specification is used to explore factors contributing to the long-run economic growth.

$Y_{i t}=\beta_{0}+\beta_{1} X_{1 i t}+\beta_{2} X_{2 i t}+\beta_{3} X_{3 i t}+\beta_{4} X_{4 i t}+\beta_{5} X_{5 i t}+\gamma_{t}+\delta_{i}+\varepsilon_{i t}$

where $\mathrm{Y}$ is per capita GDP growth rate in country $\mathrm{i}$ in year $\mathrm{t} ; \mathrm{X}_{1}$ is the capital accumulation rate in country $\mathrm{i}$ in year $t ; X_{2}$ is the population growth rate in country $i$ in year $t ; X_{3}$ is the share of research and development expenditure in country i's GDP in year $t$; $X_{4}$ is the primary completion rate in country $i$ in year $t$; $X_{5}$ is the share of imports and exports in country i's GDP in year $t ; \gamma_{t}$ and $\delta_{i}$ are time and country fixed-effects variable to capture the unobserved effects across time and countries respectively, and $\varepsilon_{i t}$ is random error.

The capital accumulation rate is expected to have a positive sign, because high capital accumulation rate enhances the available capital in the production and accelerates the economic growth rate. The population growth rate has a positive impact on GDP growth rate, as high population growth adds to the available labor force within a country and contributes to economic development. The sign of research and development expenditure is anticipated to be positive as investment in research and development stimulates technological advancement, which accelerates a country's economic growth. The primary completion rate is a proxy for human capital in a country and is expected to have a positive effect. Higher primary completion rate indicates larger well-educated work force in a country which improves productivity and therefore the economic growth. Higher share of exports and imports in GDP indicates larger trade volume and is expected to be positively related to economic growth.

\footnotetext{
${ }^{1}$ Innovative $R \& D$ is that firms engage in to develop new, higher quality products, whereas imitative R\&D is that firms involve creating differentiated versions of existing products.
} 


\section{DATA}

This study compiles annual data from the World Bank and the United Nations. Variables including per capita GDP growth rate, population, the share of research and development expenditure in a country's GDP, primary completion rate, and the share of imports and exports in GDP are from the world development indicator database of the World Bank. Capital expenditure is obtained through the United Nations website. Thus, for the variable - capital accumulation rate in the regression, we calculate the percentage change of capital expenditure over various years for each country. The dataset covers 19 countries in the America continent ranging from 1996 to $2005 .^{2}$ The descriptive statistics of the variables are shown in Table 1.

Table 1

\begin{tabular}{|l|c|c|c|c|c|}
\hline & Observation & Mean & $\begin{array}{l}\text { Standard } \\
\text { Deviation }\end{array}$ & Min. & Max. \\
\hline $\begin{array}{l}\text { GDP Growth Rate } \\
\text { (percent) }\end{array}$ & 190 & 3.1284 & 3.51945 & -11.0319 & 18.2866 \\
\hline $\begin{array}{l}\text { Capital Accumulation Rate } \\
\text { (percent) }\end{array}$ & 182 & 3.8005 & 14.8224 & -36.7114 & 100.6472 \\
\hline $\begin{array}{l}\text { Population Growth Rate } \\
\text { (percent) }\end{array}$ & 190 & 1.5605 & 0.5420 & -0.1507 & 2.5699 \\
\hline $\begin{array}{l}\text { Primary Completion Rate } \\
\text { (percent) }\end{array}$ & 149 & 90.4535 & 12.5608 & 48.0154 & 110.9569 \\
\hline $\begin{array}{l}\text { Share of Research and } \\
\text { Development Expenditure in } \\
\text { GDP (percent) }\end{array}$ & 129 & 0.6298 & 0.7465 & 0.0301 & 2.7613 \\
\hline $\begin{array}{l}\text { Share of Exports and Imports } \\
\text { in GDP (percent) }\end{array}$ & 190 & 62.7502 & 32.6835 & 19.35 & 159.70 \\
\hline
\end{tabular}

\section{EMPIRICAL RESULTS}

The regression results of the econometric specification are presented in table 2. The first regression is Ordinary Least Square (OLS) estimation. The drawback of the OLS estimation is the omitted variable bias which does not control for factors constant over time yet differing between countries or factors differing over time yet constant between countries. Hence, in the second regression, we employ the random-effects estimation that controls for year and country fixed-effects. As shown in Table 2, the estimated coefficients remain similar in both regressions and statistical significance is improved slightly in the random-effects estimation. ${ }^{3}$ Furthermore, all of the variables exhibit the expected signs in both regressions. Specifically, the coefficient of capital accumulation rate is positive and significant at the $1 \%$ level which indicates that capital is an important contributor to economic growth. The sign of population growth rate is in line with the prediction of the Solow model; yet it is insignificant. Primary completion rate is correctly signed and significant at the $10 \%$ level in the random-effects estimation, thus supporting the hypothesis that well-educated labor force improves labor effectiveness and therefore economic growth. Even though the coefficient of Share of Research and Development in GDP has the appropriate sign, it is not significant. The variable Share of Exports and Imports in GDP has a positive sign and significant at the 5\% level. This result is in line with other studies regarding country openness and trade liberalization as determinants of economic growth.

\footnotetext{
${ }^{2}$ The countries included in the dataset are United States, Brazil, Canada, Mexico, Argentina, Venezuela, Colombia, Chile, Peru, Ecuador, Guatemala, Costa Rica, Uruguay, Panama, El Salvador, Bolivia, Paraguay, Honduras, and Nicaragua.

${ }^{3}$ A Hausman test is run to choose between fixed-effects and random-effects regression. The Hausman test fails to reject the null hypothesis that fixed-effects estimate are not statistically different from random-effects estimates, which indicates that randomeffects estimates are preferred to random-effects estimates.
} 
Table 2

\begin{tabular}{|l|c|c|}
\hline & $\mathbf{( 1 )}$ & (2) \\
\hline & OLS & $(0.160$ \\
\hline Capital accumulation Rate & 0.180 & $0.00)^{* * *}$ \\
\hline Population Growth Rate & $(0.000)^{* * *}$ & $(0.254)$ \\
\hline & 0.854 & 0.082 \\
\hline Primary completion Rate & $(0.237)$ & $(0.079)^{*}$ \\
\hline & 0.072 & 0.346 \\
\hline Share of Research and Development in GDP & $(0.107)$ & $(0.477)$ \\
\hline & 0.320 & 0.025 \\
\hline Share of Exports and Imports in GDP & $(0.522)$ & $(0.013)^{* *}$ \\
\hline & 0.025 & Yes \\
\hline Year Fixed Effects & $(0.018)^{* *}$ & Yes \\
\hline State Fixed Effects & No & -7.027 \\
\hline Constant & No & $(0.146)$ \\
\hline & -7.477 & 17.17 \\
\hline Hausman Test & $(0.123)$ & $(0.1916)$ \\
\hline Observations & & 96 \\
\hline R-squared & 96 & \\
\hline
\end{tabular}

Note: $\mathrm{p}$ values in parentheses. * significant at $10 \%$; ** significant at $5 \%$; *** significant at $1 \%$.

\section{CONCLUSION}

This paper investigates factors contributing to economic growth using data covering the years 1996-2005 for American countries. The findings in this paper support the Solow growth model and other previous studies on economic growth. Capital accumulation rate, the education of a country's labor force, and trade liberalization are important determinants of economic growth. Population growth and investment in research and development are positively related to economic growth, though the impacts are not statistically significant. This finding suggests that even though population increment can contribute to a country's economic growth, excessive population increase is likely to undermine economic development. As Davidson and Segerstrom (1998) suggested, the impact of research and development investment on economic growth depends on whether the outcome of research and development is innovative or imitative. The innovative research and development leads to faster economic growth, while the latter is related to a slower growth. Furthermore, the impact of research and development may also depend on whether a sufficient absorptive capability of the advanced technologies is available in the economy. Hence, a future extension is to employ the education attainment to measure the absorptive capability of the advanced technologies in a country and to examine the threshold level of education attainment above which research and development affects economic growth significantly.

\section{AUTHOR INFORMATION}

Hong Zhuang is an assistant professor of economics at Indiana University South Bend. Dr. Zhuang receives her $\mathrm{PhD}$ from University of Oregon, Eugene, Oregon, U.S.A. Her specialized field is international economics and economic growth.

Robert St. Juliana is an undergraduate student at Indiana University South Bend. He majors in economics.

\section{REFERENCES}

1. $\quad$ Arestis, P., Demetriades, P. O., \& Luintel, K. B. (2001). Financial Development and Economic Growth: The Role of Stock Markets. Journal of Money, Credit and Banking, 33(1), 16-41.

2. Atje, R. J., Boyan. (1993). Stock Markets and Development. European Economic Review, 37(2), 632-640. 
3. Coe, D., \& Helpman, E. (1995). International R\&D Spillovers. European Economic Review, 39(5), 859887.

4. Davidson, C., \& Segerstrom, P. (1998). R\&D Subsidies and Economic Growth. The RAND Journal of Economics, 29(3), 548-577.

5. Helpman, E. (1981). International Trade in the Presence of Product Differentiation, Economies of Scale, and Monopolistic Competition: A Chamberlin-Heckscher-Ohlin Approach. Journal of International Economics, 11(3), 305-340.

6. Jones, C. (2002). Sources of US Economic Growth in a World of Ideas. The American Economic Review, 92(1), 220-239.

7. Krugman, P. (1979). Increasing Returns, Monopolistic Competition, and International Trade. Journal of International Economics, 9(4), 469-479.

8. Levine, R., \& Zervos, S. (1998). Stock Markets, Banks, and Economic Growth The American Economic Review, 88(3), 537-558.

9. Romer, P. (1990). Endogenous Technological Change. Journal of Political Economy, 98(5), S71-S102.

10. Tobin, J. (1965). Money and Economic Growth. Econometrica, 33(4), 671-684.

11. Xu, B., \& Wang, J. (1999). Capital Goods Trade and R\&D Spillovers in the OECD. Canadian Journal of Economics, 32(5), 1258-1274. 
NOTES 